\title{
Thinking on Special Education Teachers' On-the-job Training Based on the Professional Standard for Special Education Teachers
}

\author{
Xiu Li* \\ College of the Special Education \\ Leshan Normal University \\ Leshan, China
}

\begin{abstract}
The quality of front-line special education teachers directly influences the right of exceptional children to receive education and the quality of special education. The Professional Standard for Special Education Teachers issued by the Ministry of Education in 2015 proposed new requirements for the special education teachers' professional concept, professional knowledge and skills and clearly addressed the Professional Standard for Special Education Teachers is the important basis of the training and self-development of special education teachers. According to the current situation of performance and training of front-line special education teachers, this paper teases and concludes teachers' education background and professional quality, the times, frequency, forms, contents and evaluation of the training, deeply analyzes problems in training and offers a proposal based on the Professional Standard for Special Education Teachers, looking forward to providing basis for the training of special education teachers.
\end{abstract}

Keywords—special education teachers; professional standard; on-the-job training

\section{INTRODUCTION}

In August 2015, the Ministry of Education issued the Professional Standard for the Special Education Teachers, referring to an important measure for the implementation of spirit in documents like the Outline of the National Medium and Long Term Education Reform and Development Plan (2010-2020) and the Special Education Promotion Plan (20142016) as well as Opinions on Strengthening the Construction of Teaching Staff issued by the State Council in the special education field, as well as a landmark issue in the history of special education. The introduction of professional standard is the requirement to implement the national education plan, improve the specialization of special education teachers, also conforming to the development trend of standardization of international special education teachers. [1] The Professional Standard has requirements of three basic contents for special education teachers. The contents are divided into fourteen fields and sixty-eight items. In the suggestion of implementation, it proposes the education administration departments at all levels should take the Professional Standard as the fundamental basis for the construction of special

* Li Xiu, female, master in special education, instructor, researches on teacher training in special education education teaching staff, fully exert the leading role of the Professional Standard and continuously improve the training quality of special education teachers; universities of special education shall take the Professional Standard for the Special Education Teachers as the basis to train teachers, improve the training scheme and scientifically provide the educational curriculum as well as reform the education style; schools (institutions) of special education shall take the Professional Standard for the Special Education Teachers as the important basis of teacher management and promote teachers' professional development through the school-based teaching research and training; the special education teachers should take the Professional Standard for the Special Education Teachers as the basis of their professional development and actively participate in the training and independent advanced study and training, so as to gradually improve the professional development level. [2]Therefore, the Professional Standard for the Special Education Teachers has new requirements for the on-the-job training of special education teachers.

\section{CURRENT SituAtion OF THE SPECIAL EDUCATION TEACHERS IN OUR COUNTRY}

\section{A. The Level of Special Education Teachers' Education Background Is Low.}

Special education teachers with the initial education background graduate from secondary normal school and technical secondary school, accounting for about half of the total number of teachers. Teachers graduating from junior college and regular college account for about a quarter of the total number respectively. At present, most special education teachers have bachelor degree, the number of which is over fifty percent. The next one is the teachers with college degree, accounting for $30 \%$. Although the level of special education teacher's education background is improved through post-job training, compared with the developed countries, the level is low, failing to meet the actual demands of special education. [3] According to the statistics on the education yearbook, full-time special education teachers with graduate degree and bachelor degree account for $1.8 \%$ and $57.8 \%$ respectively, teachers with college degree account for $35.3 \%$ and teachers with senior high school degree and below account for $4.1 \%$. Full-time 
teachers having received special education training account for $64 \%$, the proportions are $71.4 \%, 67 \%, 60.3 \%$ and $55.6 \%$ for graduate degree, bachelor degree, college degree and senior high school degree respectively, and only $29.5 \%$ of teachers below the senior high school degree. (See table 1) [4]

TABLE I. EDUCATION BACKGROUND OF FULL-TIME TEACHERS IN SPECIAL EDUCATION SCHOOLS IN 2004

\begin{tabular}{lllllll}
\hline & Total & $\begin{array}{c}\text { Gradua } \\
\text { te } \\
\text { degree }\end{array}$ & $\begin{array}{c}\text { Eachel } \\
\text { or } \\
\text { degree }\end{array}$ & $\begin{array}{l}\text { Eollege } \\
\text { degree }\end{array}$ & $\begin{array}{l}\text { Senior } \\
\text { high } \\
\text { school } \\
\text { degree }\end{array}$ & $\begin{array}{l}\text { Below } \\
\text { senior } \\
\text { high } \\
\text { school } \\
\text { degree }\end{array}$ \\
\hline Total & 48125 & 846 & 27833 & 17473 & 1912 & 61 \\
\hline Female & 34988 & 652 & 20629 & 12603 & 1064 & 40 \\
\hline $\begin{array}{l}\text { Received } \\
\text { professio } \\
\text { nal } \\
\text { training } \\
\text { of special } \\
\text { education }\end{array}$ & 30802 & 604 & 18643 & 10544 & 993 & 18 \\
\hline
\end{tabular}

B. The Specialty of Special Education Teachers Doesn't Match the Job and Their Professional Level Is Low

Teachers initially majoring in the special education only account for $30 \%$. Most teachers are ordinary normal graduates not in special education major. Some even be blind to the special education in the pre-service training and don't know the children with special needs, let alone reaching the professional level of special education. Most teachers don't receive the systematic training of knowledge and skills in special education before engaging in special education. In the post-job training, although their education background is improved, they receive the professional education in the field of general education instead of the training of knowledge and skills in the special education. Obviously, the level of education background is improved, but the professional quality of special education still fails to get the substantial improvement. [3]

\section{The Professional Quality of Special Education Teachers Is Mediocre}

The overall professional quality of special education teachers is mediocre. Problems exist in the professional knowledge and skills. In regard to the professional knowledge, teachers know little about the evaluation methods for the education of exceptional children, such as the course evaluation, ecological evaluation and dynamic evaluation as well as lack the scientific understanding of specific evaluation methods like observational method and interviewing method. Some teachers understand very few about the basic theory, basic policy, education system, basic idea and development tendency (integrated education) of special education. Moreover, some teachers hold a negative attitude towards the learning of basic idea in special education, which is unimportant in their opinion. They think it is enough to grasp the specific teaching skills and meet the teaching needs, indirectly reflecting their ignorance for the learning of basic theory in special education. They are unfamiliar with the mental development and education of exceptional children. In regard to the professional skills, they lack the skills and strategies in teaching exceptional children, formulating and implementing the individualized education program. On one hand, the special education teachers don't have many opportunities in formulating the individualized education program, the ideas and practice of which are not roundly popularized in schools for the deaf and the blind and are not heard by some teachers. On the other hand, the formulation and implementation of individualized education program is not sound, failing to meet students' requirements. [3]

\section{CURRENT SituAtion OF THE POST-Job Training FOR SPECIAL EDUCATION TEACHERS IN OUR COUNTRY}

\section{A. The Times and Frequency of Post-Job Training Fail to Meet Teachers' Demands}

On the whole, the special education teachers cannot receive much post-job training. Each teacher can receive 1.6 times training yearly on average at most on a national scale. Teachers think the professional training of special education for them is insufficient. With respect to the time of training, more than $80 \%$ of teachers believe the training received by them is very insufficient, failing to meet their demands. Only about $20 \%$ of special education teachers think the training is basically enough or enough. [3] The research results of Yang Guangxu show the class hour for special education teachers in the training of new teachers is low. The class hour for the training of $32.1 \%$ of teachers is within sixty. One fifth teachers directly go to work without receiving the training. In summary, the class hour of new teacher training for about $52.2 \%$ of teachers is less than sixty and even zero. [5]

\section{B. The Training Contents and Forms Have Difference between Supply and Demand}

The training contents lay particular stress on theory without strong pertinence, failing to meet the actual demands of frontline teachers [6] and lack the training of applied skills. The findings of Yang Guangxue show the special education courses taking by teachers in the training mainly include the introduction to special education and the psychology of exceptional child, but fewer people take courses like special education curriculum and teaching, research method of special education, pathology for exceptional children and assessment of special children. Most training contents are confined to the special education field, involving very few knowledge of other disciplines related to the special education. Besides, the training pays more attention to the ideological cultivation, the update of professional knowledge, teaching skills and educational technology instead of the knowledge of humanities and social sciences as well as the scientific research on education. Teachers mainly receive the training of professional theory, and then the professional theories and skills. More theory than practice and the lack of multi-disciplinary and technical training will inevitably result in the unsound knowledge system of teachers, weak consciousness and ability in the scientific research on education, adverse to the selfgrowth and professional development of in-service teachers. The training forms for special education teachers focus on the 
lectures given by experts and the proportion of people is $73.2 \%$. Other forms include subject teaching seminar, field visit and investigation, subject research as well as the leading of famous teachers, but the proportion of people is under 50\%. It shows the training form is single. [5] Furthermore, people participating in the training have different qualities. The training doesn't take the individual difference of people into consideration [7], lacking of continuity [8]. The assessment for teachers receiving the training is not timely and reasonable [6] even doesn't exist.

\section{Low Evaluation of the Training Effects}

Some investigations show some teachers doubt the training. They think the training is not practical, systematic and targeted. It needs further improvement in grasping the advanced knowledge. The training cannot meet their demands in professional development. Teachers of education for mentally retarded children hold the most negative attitudes toward the training effects. [6] According to Lai Xiaojin's survey on the on-the-job training in special education schools of Dalian city, the results show forty-eight percent of teachers think the training effect is mediocre; eight percent of teachers think the training is unfruitful. The proportion of more than fifty percent shows the effect of on-the-job training for special education teachers is unsatisfactory. Teachers also think training institutions and schools neglect the demands of them, with single training method and the "duck-stuffing" type of teaching instead of considering the characteristics of the learning of adults. The provision of training contents is unreasonable, having no regard for teachers' actual demands. Moreover, teachers also reflect the incentive mechanism and evaluation system of on-the-job training for special education teachers need improvement. The evaluation of on-the-job training often adopts the summative evaluation through checking attendance and written examination. Some training even doesn't have assessment. [6]

\section{SUGGESTIONS FOR THE ON-THE-JOB TRAINING OF SPECIAL EDUCATION TEACHERS}

\section{A. Establish a Formal Training System}

The requirements of on-the-job training for special education teachers are stipulated in detail in the American federal law and state laws. The Amendments to the Education Act of the Education of People with Disabilities 2004 regulates the funding source, administrative department, training institutions and training contents for the on-the-job training of special education teachers; some states stipulate teachers shall obtain the master degree within five years after getting the junior certificate. Some stipulate new teachers must update the professional qualification every five years after getting the professional qualification via performance evaluation. [9] The Article 17 of the Teacher's Law in Taiwan expressly stipulates teachers have the obligation of engaging in advanced studies. The concrete contents are covered in the In-service Training Methods for Teachers in Senior and Secondary Schools and below and Kindergartens, requiring teachers "must learn eighteen class hours or obtain one credit at least in one academic year, or learn ninety class hours or obtain five credits within five years". [10]

Although there are also provisions of laws and regulations concerning teachers' on-the-job training in Chinese mainland, the contents are macroscopic, lacking provisions on the operational level. Therefore, it is suggested: Refer to the advanced practice in America and Taiwan and determine the funding, administrative department, training contents and cycle of teachers' on-the-job training in the forms of related laws and regulations, making teachers' post-job training normal, long-term and normalized. Establish the training system of "pre and post integration" and "participation of three sides" on the basis of existing on-the-job training system for special education teachers. The "pre and post integration" means the integration of pre-job training and post-job training. The postjob training becomes the extension of teachers' professional learning; the "participation of three sides" refers to the joint participation of education authorities, special education universities and special education schools. The Ministry of Education takes the lead and the Education Department (Bureau) of provinces and cities sets standards of special education teachers' education background, qualification and professional skills; special education universities organize the training under the guidance of education authorities; special schools support teachers to attend the training in classroom management system, working arrangement and finance, to form the three-dimensional training system with cooperation of three sides.[11]

\section{B. Optimize the Setting of Training Courses}

According to the feedback of training contents, quite a number of teachers think the training contents are too theoretical and divorced from teaching practice. Therefore, it is an effective way to improve the effectiveness of on-the-job training through actively investigating and surveying before training to know about teachers' requirements, meanwhile timely paying attention to the dynamic information of related policies, and then setting the course contents to let the training keep pace with the times. The setting of course contents should consider from two aspects: firstly, the good mental health status of teachers plays an important role. Some existing findings show the special education teachers have quite prominent work stress and job burnout. Therefore, the on-thejob training should pay attention to the knowledge and ability of teachers in teaching exceptional students as well as their mental health status. The psychological health and adjustment of teachers should be taken into consideration. Secondly, consider the professional literacy of teachers in special education. The Professional Standard for the Special Education Teachers issued in September 2015 by the Ministry of Education proposed three requirements: professional concept and teachers' ethics, professional knowledge and professional skills. The setting of training courses on one hand shall consider teachers' actual demands and on the other hand base on the professional standard for teachers. It mainly includes:

1) The teachers' psychological health: Teachers are the key to the development of special education. The advanced educational idea, correct education belief and healthy 
psychology as well as personality traits of teachers are the guarantees of the professional development of special education teachers. [12] It is a long, hard process with slow effect to educate exceptional children. In recent years, the degree of disability of exceptional students is increasingly severe, the types are more and more diversified and the difference between students is greater. These changes give requirements and challenges for teachers in rehabilitation technology (occupational therapy, physical therapy and art therapy) except for the traditional subject teaching. The longterm low sense of achievement is easier to result in teachers' work stress and job burnout. Therefore, the training should contain the common sense of psychological health and train teachers' skills of psychological adjustment, in order to improve their ability of psychological self-regulation and let them adjust emotions and behaviors rationally.

2) Education courses of teacher's ethics: The level of teacher's ethics determines whether the special education teachers are qualified, deciding the level and quality of special education. The transformation of contemporary society causes the change of social values and influences people's cognition and evaluation of teaching profession. The special education teachers are neglected by people. Therefore, many students are not willing to choose the special education specialty after the college entrance examination and don't have the professional ideal to engage in the special education. [13] Influenced by the working conditions, wage and treatment, occupational reputation and social recognition, the special education teachers have weak occupational emotion. Job burnout has become an issue worthy of attention and urgent solution. Special education teachers have vague service scope and weak service awareness. In the training of teacher's ethics, we can refer to the training of special education teacher's professional quality in America, pay attention to guiding teacher's professional ideal and training occupational emotion. Besides, we can help teachers to clarify the service scope, strengthen the service awareness, so as to improve special education teachers' ethics. In the education of teacher's ethics, we should base on the "people oriented" principle, fully consider teachers' demands and emotion changes, timely and calmly help them to analyze the reasons, get rid of troubles and hold correct attitudes toward the setbacks.

3) The course of professional knowledge: It mainly includes: 1) the knowledge about the rehabilitation medicine. It clearly points out in the Special Education Promotion Plan that teachers shall reform the education and teaching methods, strengthen the individualized education, the pertinence and effectiveness of education. The experiment of "connection of medicine and education" is conducted to improve disabled students' rehabilitation level and ability of knowledge acceptance. The professional standard for special education teachers also requires teachers to know about the basic knowledge and method of rehabilitation. The special education has close relationship with rehabilitation medicine, psychology and pedagogy. It is the intersection of multiple disciplines. Therefore, special education teachers should learn a vast amount of knowledge including the rehabilitation medicine, educational psychology and education and teaching theory, especially the knowledge about the rehabilitation medicine. 2)
Professional knowledge of discipline. The Professional Standard for special education teachers proposes teachers should grasp the basic contents, basic thoughts and ideas of their disciplines as well as the relation with other disciplines and social life. The research [13] of Ai Chun shows the knowledge and ability that the special education teacher shall have in teaching disciplines haven't got enough attention, such as the ability in formulating and executing the IEP, the ability to cooperate with students' parents and the community, the ability in action research and independent development. The pre-job training lacks courses related to the disciplines taught in the future. Therefore, the special education teachers are short of the disciplinary knowledge in course development and teaching design. The knowledge structure of related disciplines is unsound and uneven.

4) Course of professional skills. It mainly includes: 1) the skill to formulate and implement the individualized education program 2) the skill to create and use the environment 3 ) the skill to evaluate students' school work 4) the skill to carry out the teaching reflection. Zhao Xiaohong and Hua Guodong address the special education teachers of our country "pay attention to the needs of the class and easily neglect students' individual difference; the quality of teachers is uneven and it lacks professionals; the national unified educational plan and classroom teaching focus on the class-based teaching; it mainly adopts the "division of work system" instead of the "system of taking all responsibilities"; officially, it hasn't introduced the official evaluation system related to the individualized education program, so it is impossible to supervise and evaluate the implementation of IEP." [14] The Education for All Handicapped Children Act in America protocols the IEP as the legal project for the exceptional children, requiring the special education teachers to formulate the "Individualized Education Program" for each exceptional child, including five contents. What Special Educations Must Know-About International Standards for the Preparation and Qualification of Special Education Teachers formulated by the Council for Exceptional Children in 1995 clearly requires the special education teachers shall have the following professional qualities: 1) Strong manipulative ability. Teachers should be able to provide "safe, positive and helpful learning environment" for students. The environment includes hardware conditions include the campus and classroom as well as software conditions like the textbooks, teaching and learning aids, teaching technique and teaching strategies. Teachers should learn to make use of the environment and design, transform and set the environment in person instead of waiting and dependence. 2) Be flexible according to physical truth. According to the situation and requirements of special students, teachers should be able to "adjust the environment to meet students' requirements". It proposes teachers can "adapt the teaching materials", "choose, change and implement the classroom management strategies for students", "use strategies and technologies convenient for students to integrate in different environments". CEC doesn't advocate the sameness of environment, contents and methods of special education as well as the invariability of a textbook. Teachers shall not repeat what the book says in teaching. 3) Specialized knowledge and skills. CEC has many targeted special requirements for teachers teaching different kinds of special 
students. For example, the teachers of education for the deaf should understand "elements influencing the deaf culture of classroom management in schools for the deaf"; teachers of education for students with emotional and behavioral disorders shall "record students' behavior changes". [13]

\section{Explore the Classified Training Mode}

Because of the differences in experience, education background, title and professional background, the special education teachers have different requirements for the training. At present, the on-the-job training for teachers is classified according to the education for three kinds of disabled students. There is no more detailed classified training mode except for this. It is difficult for the unified training mode without paying attention to teachers' differences to achieve the actual effects.

The on-the-job training for special education teachers should be multi-layered, including the city level, provincial level and national level. Trainings at different levels should have different training needs, range of application and training contents. [15] Special education teachers with different professional background (whether graduate from specialties related to the special education), experience and education background have different requirements for the training. For example, the experienced teachers can better grasp the basic professional knowledge and skills of the special education specialty, but failing to understand the advanced dynamic information of the new professional fields as well as answer the education and rehabilitation technology of more diversified educational object, such as the education of students with infantile autism, the idea and implementation of the individualized education program; on the contrary, young teachers with less experience lack the ability to apply the advanced educational idea and the technology of education rehabilitation to the practice. Teachers not graduating the special education specialty (graduate from the subject education specialty) have clear logical system and ability of subject teaching but fail to deeply understand the characteristics of physical and mental development of special students, principles, ways and methods of teaching and education; on the contrary, teachers graduating for the special education specialty can understand the characteristics of physical and mental development of special students as well as design and execute the individualized education according to the differences of students, but they fail to roundly understand and correctly grasp the knowledge system of disciplines taught by them. Therefore, it often appears the chaos that the contents in grade three of ordinary primary schools are taught in grade two of special schools.

Therefore, it is necessary to train according to the age and professional background of special education teachers, provide training courses in line with the actual demands of different teachers and choose teachers suitable for the training. It can guarantee the actual effects of on-the-job training for special education teachers through sound classified training mode, actually paying attention to the demands of teachers participating in the training.

\section{Establish the Training Evaluation Mechanism}

The research results of Zhu Lin show the low efficiency of training is related to the lack of effective on-the-job training evaluation system. [7] At present, the evaluation of on-the-job training for special education teachers only investigate the satisfaction degree of teachers in the training, instead of evaluate the training results of teachers. Without assessment, no pressure will exist, let alone motivation. Therefore, some teachers participating in the training are absent without any reason, late for the training and go in and out in class. According to the experience of developed countries, we should combine the training with promotion and assessment to improve teachers' quality, taking the on-the-job training for teachers as a necessary condition of promotion and establishing the related supporting systems. [16] Besides, strengthen the supervision and assessment as well as establish a strict management system. It is necessary to assess the theoretical knowledge of teachers after the training and reflect the practice activities through job record, taking the evaluation results of theory and practice as the evidence to identify teachers' continuous employment and the class hours of continuing education.

Furthermore, establish the unified training network at different levels for teachers and detail the functions of departments: the training base formulates and implements the training plan, the management organization checks the training plan, supervise the training process and assess the training results. All are responsible and supervise each other, so as to guarantee the effectiveness of on-the-job training for special education teachers.

\section{CONCLUSION}

In conclusion, the Professional Standard for Special Education Teachers has new requirements for the professional idea, knowledge and skills of special education teachers. It is an important basis of the training and self-development of special education teachers. Therefore, it also has new demands for the on-the-job training, further education and continuing education of them. In order to better meet the requirements of development of the modern special education and serve the education of disabled students, the on-the-job training for special education teachers should base on the Professional Standard for Special Education Teachers, reform the evaluation of training contents, forms and effectiveness, in order to improve the effectiveness.

\section{REFERENCES}

[1] Ding Yong. Guidance of Special Education Teachers' Professional Growth via Professional Standard [J], A Journal of Modern Special Education (Higher Education), 2015, (9): 3-8.

[2] http://www.moe.edu.cn/srcsite/A10/s6991/201509/t20150901_204894.h tml

[3] Wang Yan, etc. Research on the Training of Chinese Special Education Teachers [M], Beijing: Beijing Normal University Press, 2011

[4] http://www.moe.gov.cn/s78/A03/moe_560/jytjsj_2014/2014_qg/201509 /t20150901_204567.html 
[5] Yang Guangxue, Yang Fuyi, etc. Report on the Investigation of Chinese Special Education Teachers' Professional Development and Policy Analysis [M], Shanghai: East China Normal University Press, 2014

[6] Lai Xiaojin. Research on the Investigation of Current Situation of Onthe-job Training for Teachers in Special Education Schools of Dalian City [D], Dalian: Liaoning Normal University, 2012

[7] Zhu Lin, Sun Ying. Investigation of the Training Status of Special Education Teachers in Beijing City [J], Chinese Journal of Special Education, 2011, (8): 20-24

[8] Ma Renhai. Establishment of On-the-job Training Mode for Teachers in Special Schools of Hubei Province [D], Wuhan: Central China Normal University, 2006.

[9] Yuan Jun, Bi Cheng. Brief Introduction to the Educational Evaluation System of American Pre-service and In-service Teachers [J], Studies in Foreign Education, 2004, (11): 56-60

[10] Zhuang Suzhen, Yuan Dong. Comparison of Training Systems for Visual Impairment Education Teachers in Taiwan and Chinese Mainland-Taking National University of Tainan and Nanjing Technical College of Special Education as Examples [J], Journal of Special Education and Rehabilitation, 2011, 06(24): 57-59

[11] Wu Xiaoya. Analysis on the Current Situation of On-the-job Training for Special Education Teachers in America and China [J], A Journal of Modern Special Education, 2009, (9): 18-20

[12] Zhao Qiaoyun. Rustic Opinions on the Professional Development Standard for Special Education Teachers of Our Country [J], Chinese Journal of Special Education, 2009, (4): 14-18

[13] Ai Chun. Comparative Study on the Professional Quality of Special Education Teachers in Chinese and American Middle and Primary Schools [D], Changchun: Northeast Normal University, 2008

[14] Zhao Xiaohong, Hua Guodong. Application of Individualized Instruction and Differentiated Teaching in the Special Education [J], Chinese Journal of Special Education, 2006, (8): 40-45

[15] Wang Xiuli. Research on the Current Situation of On-the-job Centralized Training for Teachers in Schools for Intellectual Disability [D], Dalian: Liaoning Normal University, 2014

[16] Gao Lei. Establishment of School-based Training System for Young Teachers in Special Education Schools [J], Chinese Journal of Special Education, 2005, (12): 84-88. 